\title{
Management of skills within Moroccan companies
}

\author{
Kemal Fatima Ezzahra ${ }^{\text {A } 1}$, Radid Mohamed ${ }^{\text {A }}$, Talbi Mohamed ${ }^{\text {A }}$ \\ Laboratory of Physical Chemistry of Materials \\ ${ }^{a}$ ORDIPU, University Hassan II Mohammedia - Ben M'Sik Faculty
}

\begin{abstract}
The management of skills was for some years, one of the main projects of HRD.
How to get rid of this tool for visualization and analysis?

Management is useful at all levels of the HR processes: recruitment, career management, promotions, succession plans internal motivation...

If a setting up often seems very heavy, it should also not wanting too much. The deployment of management of skills in the business must be carefully considered.

it is first necessary to clearly define the stages and objectives of setting up.

What objectives? For whom? By whom? How? ...
\end{abstract}

Keywords:_Skill, Human Resources, Management of skills, Training, Moroccan company, Approach, Process.

\section{Introduction}

The word «Skill », as a model of human resources management, is now a subject of innovation, is mingled with many de locutions used routinely in companies and other professional bodies: Provisional job and skill management (GPEC), management of skills, management through skills, skills benchmark, logic of skills, all the locutions are flourishing.

The crisis of scientific organization characterized by mass production and division of work in simple tasks, and the appearance of "customer is king", have led companies to review their performance in terms of deadlines, variety and quality. Companies are passed, so, «the solicitation of body than that of brain," and adopted new approaches based not on positions held, but on the skills required by employees.

That is why, consultants and scientists are working on this subject for more than twenty years, as well as large and medium-sized companies have projects more or less innovative in this field, the concept of "skill" is recognized as a major in management and organizational strategy.

So we focused our searching on skills management as a very important phenomenon, and that by bearing on the progress of the project of the management of skills within the company which we did the following study.

\section{Problematical}

Moroccan companies have initiated a project of the management of skills, to accompany the technological evolution in the country. And which aims to:

- Rectifying the aging look of the pyramid.

- Develop and retain some employees,

- Provide internally to new jobs

- Replace retirements,

- Facilitate personal projects related or not with the business environment (business creation by an employee, contribution to a process of outsourcing an activity or function)

- Facilitate external mobility within a defined job policy.

And that to make a adequacy between the need (which accompanies evolution of jobs) of the company and staff skills; By seeking to update the job descriptions of staff, or by mobilizing their skills.

\section{Faced with this problematic, two questions were developed:}

- The age pyramid, aging of the company requires the appellation of graduates and prepare to have the necessary skills to their new roles, or simply manage existing skills of agents involved (do not allow them to properly performing their functions).

\footnotetext{
${ }^{1}$ Corresponding Kemal Fatima Ezzahra. Tel.: +212-667-946396

E-mail address : kemal.fatimaezzahra@gmail.com
} 
- On which leviers can we do to enable an Moroccan company to move from a logic of jobs to a logic of skills to answer efficiently and effectively to the needs and expectations of its employees?

\section{Methodology}

As we have already seen, the efficiency and competitiveness of the company no longer pass through by the_acquisition of technology or by reducing costs and headcount. The stake of the future for company depends, fundamentally, on the success of its "skills" to be conquered and develop new markets.

To adopt a skill approach becomes an essential strategic decision is to "conceive and operating the entire HR device, in the perspective of construction and development of skills" ${ }^{2}$.It changes the practices of Human Resources function and forces us to rethink each, as lever action to identify, define, develop and recognize the skills, coherent and convergent fashion.

Finally, the process skills should be conducted in a participatory way and lead to setting up of tools, simple and personalized.

Currently, there is no only one path to engage and conduct a skill approach. Practices are very heterogeneous. However, we count, as part of this research, we use the model of the MEDEF ${ }^{3}$. which sets out in its Charter of Partnership "Skills objective" of 2000, the conditions - the key to engage and succeed in such an approach:

- Integration of process skills in the overall strategy of the company.

- Involvement of the Directorate for the success of the approach.

- Implementation of tools, skills identification.

- Involve different parts of the business, design and implementation tools.

- Ownership of the process skills through coaching.

- Development of the assessment process and monitoring of employees' skills.

- focus the business organization around the process skills.

- Highlighting beside training, other avenues of skill development.

- consideration of the effects of process of skills in various dimensions of Human Resources Management of the company

In order to better understand these issues, we will try to prepare a draft establishment of a skills approach within this.

\section{The key conditions of entry into a skill approach}

The establishment of a consistent approach to management and skills development requires a big investment of time and funds to mobilize, and to ensure its success, certain conditions must be met.

\section{The concrete definition of objectives:}

The entry into a skill approach is not simply to provide the company one of the latest tools in fashion. Before initiating like this process, it is necessary to ask what the company expects a concrete decision.

As we have seen, the skills approach aims to improve the competitiveness of the company. Engaging as this type of project, the company must be satisfied that its competitiveness through mobilizing and developing the skills of its employees.

The objectives of implementation of the approach skills in the business, can find their sources:

- The identification and development of strategic skills specific to this company in order to remain competitive in the market.

- The development of the values of society in simple and operational tools.

- Making available of employees a tool enabling them to develop their skills and help control their progress.

\section{Reflection on the methodology to be adopted:}

The establishment of skills management requires prior reflection on the methodology to be implement. In general, there are two approaches to enter a skills approach.

\section{a. The comprehensive approach:}

This approach is based on the identification of all individual skills available in the company. The objective is to arrive at a comprehensive list of knowledge, expertise and interpersonal skills to be used by workers, within jobs-type, and list them in a visual cartography and flexible skills.

${ }_{2}$ Guy Le BOTERF (2000) - Construire les compétences Individuelles et Collectives - Editions d'Organisation

${ }_{3}$ MEDEF (Avril 2005) - Charte de Partenariat « Objectif Compétences » 


\section{b. The selective approach:}

This approach is based on detection and development of strategic skills of the company. The most famous model comes from the Hay method. This approach relies on the detection of critical and potential for all positions individual skills, and based on three metrics:

i. The necessary skills to fill the post:

- Technical knowledge required;

- The management skills;

- Capacity in human relations.

ii. Creative initiative :

- The reflection framework;

- The requirement and complexity of problems.

iii. Finality :

- The latitude of action;

- The broad scope of action;

- The impact on the field of action.

This second approach seems best suited for the case of the Hay methodology has been adopted in the preparation of job descriptions, and identifying key behavioral competencies of the company. Integration of the approach in the strategy the company:

"The process skills is not an end in itself, it is an element of the strategic plan of the company. It presupposes a clear understanding of the issues underlying (...) the investment is the implementation of a competency approach is not least a powerful factor in boosting the company. "

The integration of process skills in the overall strategy of the company is to define success criteria between the mobilization of skills and productive performance. The visibility of strategic issues is a prerequisite and it identifies preferred competencies of the firm, guiding the role of hierarchy and investigate the contribution of each employee in the organization.

\section{Management of skills (case study):}

\section{a. The Major Causes and objectives:}

Many reasons are causing the introduction of management skills.

Generally, rapid world changes and technology requires a change in terms of policy, the transfer of control of the production process to control the process of creating knowledge. In addition, the growing need for a work theme was required. Both factors lead to ever greater attention to the development of 'new' skills.

\section{b. Concepts and underlying visions:}

The management of skills should contribute to::

- Identifying opportunities for skills development for individual employees.

- Increased employability (to ensure that the employees have the opportunity to put their skills to work within the organization).

- Preparation of future developments, that is to say, to prepare for the future (projecting into the future and acting in anticipation of the future).

\section{c. Steps of the application of management of skills:}

The introduction of skills management process was initiated by the Human Resources Management of the company. The implementation should be done during the period of last three or four years.

The following steps can be distinguished in the process of application of management of skills:

- Selection of commercial units, which should start the process.

- Formulation of a project plan by the Director of HRM.

- Implementation of the project plan. 


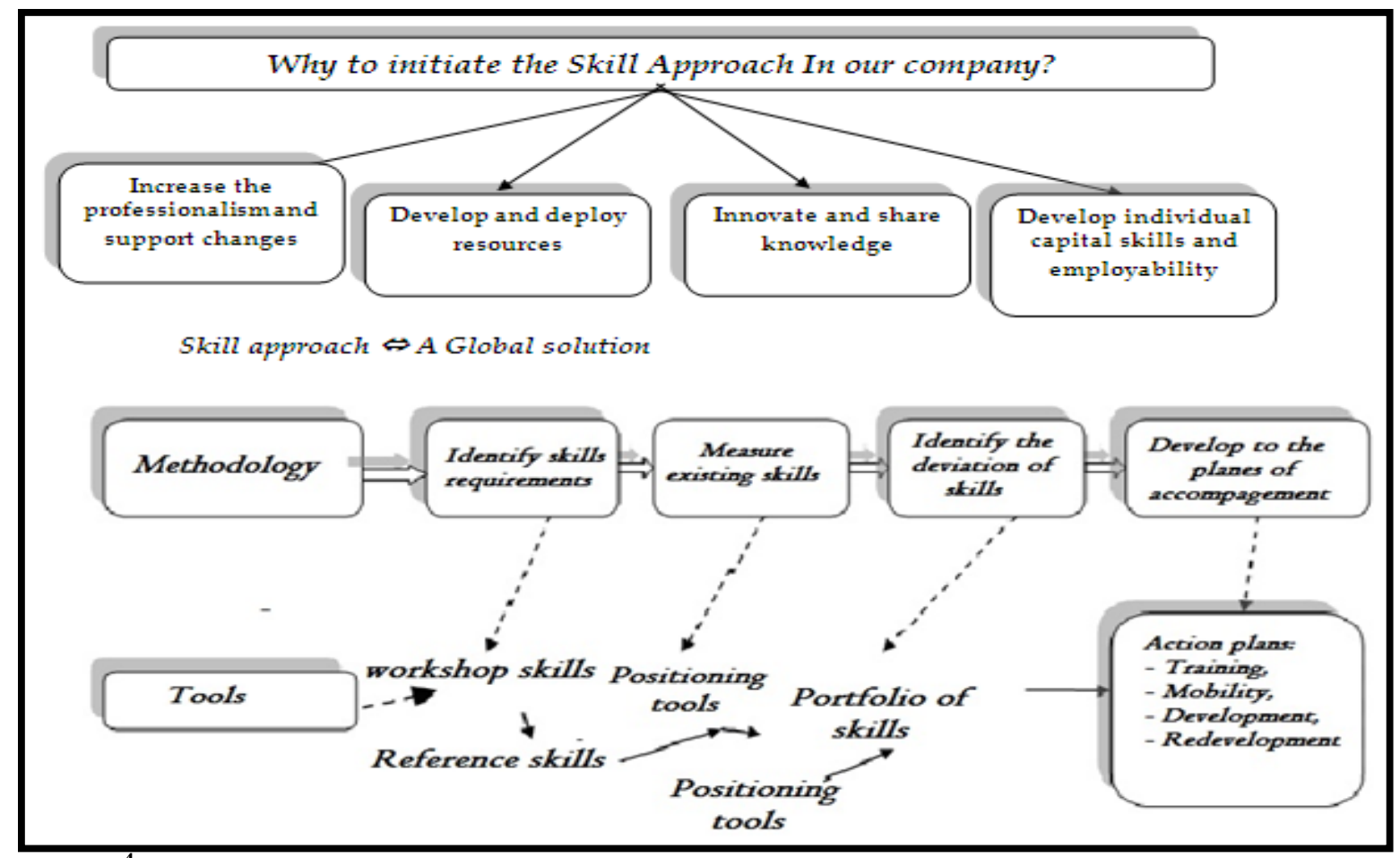

a schema ${ }^{4}$

\section{The project plan defined the following intermediate steps:}

In agreement with the employees concerned, we planned actions related to skills development, that is to say an employee training to to increase their capacities to grow within the company.

Note: skills development enables employees to acquire knowledge, skills, abilities ... beyond its current professional qualifications and which are not necessary for keeping their current job. ${ }^{5}$

This approach has passed as follows:

i. start-up

- Briefings for managers and employees (why, what, how).

- Definition of functions for which profiles should be described.

- Description of the situation "REAL".

- Description job profiles.

- Assessment of function profiles.

ii. Specification of skills for the future (position "THEORETICAL")

- Interviews with employees.

- Commercial Reviewing (What activities have been successful and what activities have failed?).

- Interviews with leaders (on the basis of commercial revisions, it was asked responsables to explain, inter alia, the deficiency in terms of skills, the analysis indicated a shortage of commercial skills and human competencies (interrelational) .

- Final description and definition of the necessary skills in the future on an organizational level.

- Definition of skills needed in the commercials units.

iii. Specification of actions in the short and long term

To determine if a training action allows the passage of the current situation to the envisaged situation, we need tot:

- Make the status of skills to the company,

- Identify employees may exercise.

\footnotetext{
${ }^{4}$ a schema representing the progress of the skill approach in company

5 AGEFOS PME 2006 - 19/01/2006 - O22P6-1.

Plan de Formation. Actions de développement des compétences Catégorie3
} 
iv. Implementation of skills management

Preparation of evaluation sheets and measuring grids, to measure to progressively achieve the objectives of the process

i. Evaluation of skills of employees to review the process used, to remedy and change or orient to efficiency

\section{the practices for managing skills "in the strong sense" are characterized by a link between the results of the evaluation and training, promotion of employee ${ }^{6}$}

Institution is considered practicing management skills when it meets the following conditions:

a) Managers and non-managers are given an appreciation which reflecting their performance,

b) The percentage of global expenditure on education in relation to the payroll is greater than $3 \%$,

c) Managers and non-managers are received periodically by their supervisor for an interview (assessment, balance sheet, perspective),

d) There is a direct or indirect link between the results of periodic evaluation of an employee and his training

e) There is a direct link between the results of the periodic evaluation of an employee and promotion.

\section{Conclusion}

By engaging in a skills approach, Moroccan companies, as we have already shown, in turn expects diverse positive effects: development of competitiveness, earnings increases, versatility and professionalism of its employees...

This employee, for their part, would a recognition of their skills, plan their personal development, improving their employability and broaden their perspective and career development.

This question is the test of truth of the process of skills. It is the essential condition for its success; and this is what makes the approach long process setting up tools more or less complicated, a true account of individual and collective skills.

Although, the employees did not engage in a device, relatively binding, that they make sure that this action is closely linked to management actions that most directly:

\section{Recommendations:}

- Not having in a hurry to recruit and to ensure that persons who will be selected, have the required skills.

- Aim HUMAN interest of the employee, except for the interest of the company (because if the employee feels good in his company he will be faithful and will give his best to this company and for long-term)

\section{Bibliographie}

[1]. GAY LE BOTHERF G., 2000, « Construire les compétences individuelles et collectives », Editions d'Organisation

[2]. LE BOTHERF, G. (1995), De la compétence - Essai sur un attracteur étrange, Editions d'organisation.

[3]. LE BOTHERF (1999) - L'ingénierie des compétences (deuxième édition) - Les Éditions d'Organisation - Paris.

[4]. MEDEF (Avril 2004) - Charte de Partenariat « Objectif Compétences »

[5]. MEDEF (Avril 2005) - Charte de Partenariat « Objectif Compétences »

[6]. Piette, S-A., \& Orban, M. (2003)- L'évaluation des compétences en milieu de travail : Leçons de quelques expériences de terrainActes du colloque ADMEE,,ULg

[7]. Thèse de Doctorat en sciences de Gestion «La gestion des compétences au sein des entreprises au Maroc, Approche duale, Perception - Pratiques - Déterminants », Lamya TERMNATI.

[8]. ZARIFIAN Philippe (1999) - Objectif compétence - Éd. Liaisons - Paris.

[9]. ZARIFIAN Philippe (1988)- «L'émergence du modèle de la compétence», Les stratégies d'entreprises face aux ressources humaines, F. Stankiewicz, Economica.

\footnotetext{
${ }^{6}$ L'étude "la gestion des compétences : un infléchissement limité de la relation salariale" est publiée dans la revue Travail et Emploi n ${ }^{\circ} 93$ de janvier 2003.
}

Diffusion : la Documentation française, 124 rue Henri-Barbusse, 93308 Aubervilliers 